AGRICULTURE AND BIOLOGY JOURNAL OF NORTH AMERICA

ISSN Print: 2151-7517, ISSN Online: 2151-7525, doi:10.5251/abjna.2010.1.6.1260.1263

(C) 2010, ScienceHuß, http://www.scihub.org/ABJNA

\title{
Provenance variation of photosynthesis of seedlings of java plum (S. cuminii) in Western Kenya
}

\author{
Okuto, J.L. and G. Ouma \\ Department of Botany and Horticulture, Maseno University \\ P. O. Box 333, Maseno
}

\begin{abstract}
Studies were conducted at Maseno University, Kenya to investigate provenance variation of gas exchange characteristics of $S$. cuminii such as stomatal conductance, photosynthesis and transpiration rates of its seedlings from three districts of Kenya namely Vihiga, Kisumu and Siaya. The studies were conducted in the years 2004 and 2005. Seeds were obtained from the fruits of S. cuminii from the three districts above using standard methods and grown in polythene pots. and watered daily two times, in the morning and evening in the pots placed in polythene-covered structures at the Kenya Forestry Research Centre nurseries at Maseno, Kenya. The experimental design was completely randomized replicated four times. When the seedlings were one month old, gas exchange parameters were determined on mature exposed leaves using an Infra Red Gas Analysis (Ciras, PP Systems, Stortfield, Hitchin, Herts, U.K) five weeks on four seedlings per plant chosen at random from each replicate. Statistical analysis was carried out on the data obtained using Analysis of Variance (ANOVA) and mean separation using the Least Significant Different Method (L.S.D). The results showed that the trends in decreasing order for photosynthetic rates were Vihiga, Kisumu and Siaya. Stomatal conductance was similar for Kisumu and Siaya but was higher than Vihiga. Transpiration rates were highest in Vihiga followed by Siaya and Kisumu provenances. The parameters decreased with age up to 56 days after transplanting then increased and peaked at 84 days after transplanting for stomatal conductance and transpiration rate and at 112 days for photosynthetic rates. It is concluded that the gas exchange parameters varied among provenances and with age of seedlings after transplanting.
\end{abstract}

Keywords: Age, provenance, seedlings, photosynthesis, stomatal conductance, transpiration.

\section{INTRODUCTION}

In sub-saharan Africa, indigenous fruit trees play vital roles in food and nutritional security, especially during periods of famine (Saka et al, 2002, 2004b, Akinnifesi et al, 2004a) although they are becoming increasingly important as a main source of food to supplement diets in better times, as in Zimbabwe where wild fruits represent about $20 \%$ of total woodland (Campbell et al, 1997). Producers can obtain substantial household incomes supplying local markets (Kaaria, 1998, Schroburg et al, 2002, Ramadhan, 2002) with women and children being the main beneficiaries.

Deforestation poses a real threat to the indigenous fruit trees and their domestication is aimed at encouraging the local people to cultivate them In Kenya, indigenous fruits are important sources of minerals and vitamins in the local diets. One of the most common indigenous fruits in Kenya is $S$. cuminii, which is predominant in the western Kenya districts of Siaya, Kisumu and Vihiga.
Several workers have reported provenance variation in gas exchange parameters in various indigenous fruit trees (Benowicza et al, 2001, Lanter, et al, 1997, Miguel et al, 2000, Ngugi et al, 2004, Benowicza et al, 1999, Benwicza et al 2000, Zhang et al, 2005, Luoma 1997). These variations have been due to genotypex environmental interactions (Benowicza et al, 2001), different climatic adaptations (Lanter, et al, 1997, genetic variations in rubulose bisphosphate carboxylase (RUBP), chlorophyll, leaf soluble protein and thickness (Lanter, et al, 1997), low values of carbon isotope discrimination among provenances due to low values of intercellular $\mathrm{CO}_{2}$ partial pressure and low mesophull conductance causing reduced $\mathrm{CO}_{2}$ partial pressure (Lanter, et al, 1997), reduction of photosynthesis due to low moisture availability which causes low carbon isotope discrimination (Miguel et al, 2000, Ngugi et al, 2004), genetic variation in adaptive attributes (Benowicza et al, 1999), variation in light (Luoma, 1997), water (Zhang et al, 2005). 
The objectives of the present study were to determine the provenance variation of $S$. cuminii in gas exchange parameters in the three districts of western Kenya namely; Siaya, Vihiga and Kisumu where the fruit is predominant.

\section{MATERIALS AND METHODS}

The study was conducted in three districts namely: Vihiga, Kisumu and Siaya which are in Western Nyanza Provinces with areas of $563.8 \mathrm{Km}^{2}, 2,600 \mathrm{Km}^{2}$ and $3528 \mathrm{Km}^{2}$, annual temperature of $14^{\circ} \mathrm{C}-18^{\circ} \mathrm{C}, 25^{\circ}$ $30^{\circ} \mathrm{C}$ and $26^{\circ} \mathrm{C}-32^{\circ} \mathrm{C}$ and altitude of $1,500-1250-$ $1,300 \mathrm{~m}, 1244 \mathrm{~m}$ above sea levels respectively. The soils vary from dark red and friable and sandy loam for Vihiga to orthic ferralsols and vert luric phaezomes to sandy and clay types for Siaya and Kisumu district respectively (Anon, 2006).

Measurements of gas exchange parameters $\left(\mathrm{CO}_{2}\right.$ assimilation rate, transpiration and stomatal conductance were taken between 9.00am and 12noon on a sunny day on exposed fourth leaf from the top. An area of $2.5 \mathrm{~cm}$ square of leaves was inserted into the cuvette of the infrared gas analyzer (CIRAS-I-PP) Systems, Stortfield, Hitchin, Hertsz, U.K). Air flow to the curette was $200 \mathrm{mil} / \mathrm{min}$ to $225 \mathrm{ml} / \mathrm{min}$ and vapour pressure of $1.2-2.4 \mathrm{kpa}$.

Fruits of $S$. cumini were collected from the three districts of Siaya, Kisumu and Vihiga and fermented in gunny bags for three days and then hauled by hand (Atangana et al, 2001). They were then cleaned and the fully occupied non-shrunken ones were selected for germination in a glass house at Kenya Forestry Research Institute, Maseno. Seedbeds were constructed by standard techniques. Eighty freshly extracted seeds were sown by spreading them evenly in each seedbed so that none lied on top of the other to avoid damping-off pathogenic attack (Gachanja, and Ilg, 1990). The seeds were covered with sand and the beds watered in the morning and evenings by watering cans. Young germinated seedlings from each district were pricked out into potted soils from the respective districts where they grew for one month before commencement of data collection. The treatments comprised sources of seedlings and these were replicated four times. The pots with the seedlings were arranged in a completely randomized design in a polythene covered structure. Data analysis was by Analysis of variance and mean separation by the Least Significant Difference method ((SAS Institute, 2001).

\section{RESULTS AND DISCUSSION}

At 28 days after transplanting Vihiga district had the highest $\mathrm{CO}_{2}$ assimilation rate. This was followed by Kisumu and Siaya districts in that order. The $\mathrm{CO}_{2}$ assimilation rates decreased at age 56 after transplanting but the three districts had more or less the same $\mathrm{CO}_{2}$ assimilation rates. At 84 days after transplanting of the seedlings the $\mathrm{CO}_{2}$ assimilation rate increased with the decreasing trends being Vihiga, Kisumu and Siaya in that order. $\mathrm{CO}_{2}$ assimilation rates were highest at day 112 after transplanting where Kisumu and Vihiga districts had similar $\mathrm{CO}_{2}$ assimilation rates which were higher than Siaya district (Provenance) (Fig. 1a). Conversely, Siaya had the highest stomatal conductance at day 28 after transplanting followed by Kisumu then Vihiga (Fig. 1b). Stomatal conductance behaved similarly with $\mathrm{CO}_{2}$ assimilation rates, decreasing from day 28 after transplanting to day 56 days then increasing from day 56 to 84 days after transplanting (Fig. 1b) when Kisumu and Siaya district had similar values.Ttranspiration rates also varied among provenances (districts) and days after transplanting. The decreasing trends were Vihiga, Kisumu and Siaya but the latter two had similar values. (Fig. 1c) at day 28 after transplanting. At age 56 days transpiration rates decreased with Vihiga provenance having the highest transpiration rates, followed by Siaya and Kisumu provenances. Transpiration rates then increased up to age 84 days after transplanting. The variations in photosynthesis, stomatal conductance and transpiration rates with age and provenances could be due to different adaptation to different climatic conditions (Luoma, 1997), genetic variation in ribulose bisphosphate carboxylase (RUBP) (Lanteri et al, 1997) and leaf conductance (Miguel et al, 2000, variation in soil fertility in the provenances (Buckley, 2005). These photosynthetic parameters increased, decreased then increased and peaked at 84 or 112 days after transplanting. These could be due to the stomatal apparatus being less efficient and not fully functional at young and old age of seedlings (Chen et al, 1999). The variations in these parameters could also be due to gene and environmental interactions (Lanteri et al, 1997); Benowicza et al, 2001). They could also be due to non-stomatal factors such as inhibition of the electron transport (Netondo et al, 2004, Sibole et al, 2003, Hall and Rao, 1994). 


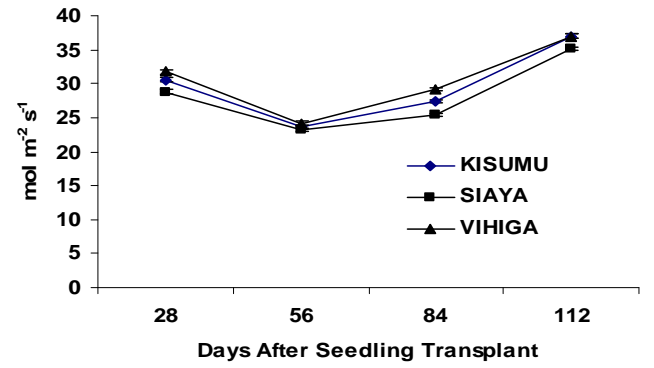

Fig.1. Carbon dioxide assimilation of S.cuminii seedlings that germinated from seeds collected from the three districts (Siaya, Kisumu, and Vihiga). Each value is a mean of four replicates \pm standard deviation.

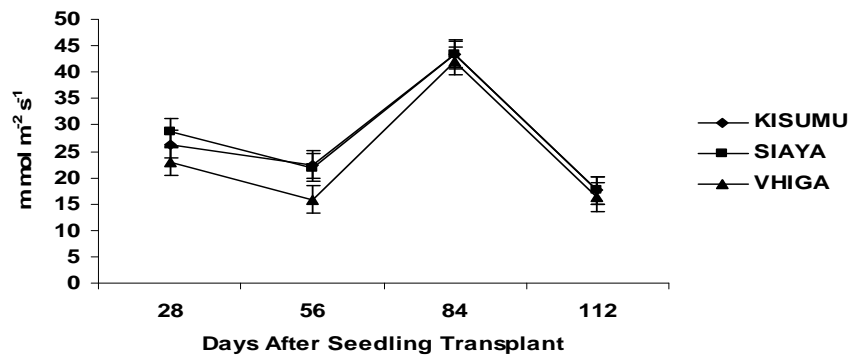

Fig. 2. Stomatal conductance of S.cuminii seedlings which germinated from seeds collected from three districts (Siaya, Kisumu and Vihiga).Each value is a mean of four replicates \pm standard deviation.

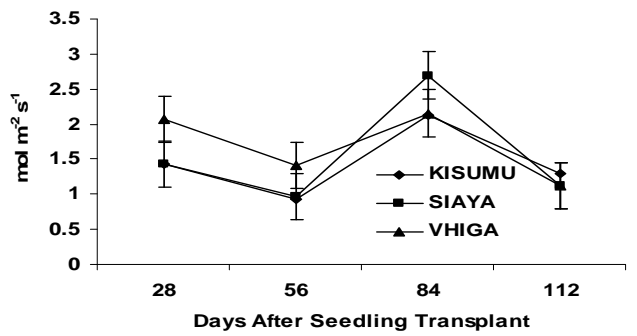

Fig. 3.Transpiration rates of S.cuminii seedlings that germinated from seeds collected from three districts (Siaya, Kisumu, and Vihiga). Each value is a mean of four replicates \pm standard deviation.

\section{REFERENCES}

Akinnifesi, F.K, Kwesiga, F.R, Mhongo, J, Mkonda, A. and Swai, R. (2004a): Priority miombo indigenous fruit trees as a promising livelihood options for smallholder farmers in Southern Africa. Proc.Agroforestry Conference on Agroforestry Impacts on Livelihoods August 2-7th Nairobi,Kenya
Benowicza A, and A. El-Kassaby (1999): Genetic variation in mountain hemlock (Tsuga mertersiana Bong) Quantitative and adaptive attributes. For Ecol and Manag.

Benowicza, A, R.D. Guy, A. El-Kassaby (2000) geographic pattern of genetic variation in photosynthetic capacity and variation in photosynthetic capacity and growth in two hardwood species from British Columbia. Oecologia Vol. 123, No. 2 Pp168 - 174.

Benowicza, A. R.A Guy, Carlson, M.R, El-Kassaby, A (2001) Genetic variation among paper birch Betula Papyrifera, Marsh populations in German, forest hardiness and gas exchange and growth. Silvae genetica Vol.50 No. 1 pp1 - 13 .

Buckley, T.N. (2005) stomatal conductance observation. New phytologist 43:168 - 292.

Campbell, B., Luckert, M.,Scoones, I. (1997) Local level evaluation of savannal resources: A study in Zimbabwe Econ.Bot, Vol. 51, No. 5 pp 57 - 77.

Chen, J.M, Liu, J., Goulden, M.I. (1999): Daily canopy photosynthesis model through temporal and spatial scaling for remote sensing applications. Ecol. Mod. 124: (1) 99+19.

Hall, D.O and Rao, K. (1994) Photosynthesis studies in Biology. Cambridge University Press, Cambridge, U.K.

Kaaria, S.W. (1998). The Economic potential of wild fruits in Malawi, M.Sc. thesis, University of Minnesota, U.S.A.

Lauteri, M, Scartazza, A, Guido, M.C, Brugnoli, E. (1997) Genetic variation in photosynthetic capacity, carbon isotope discrimination and mesophyll conductance in provenances of Castanea sativa adapted to different environments. Functional Ecol. Vol. II No.6, pp 675 683.

Luoma, S. (1997) Geographical pattern in photosynthetic light responses of Pinus sylvestus in Europe. Functional Ecol.11 (3), pp 273 - 281

Miguel, J. Olivas, G, B.M. Cregg and J.C. Hennessey (2000) Genetic variation in carbon isotope discrimination and gas exchange of ponderosa pine seedlings under two levels of water stress. Can J. For Res. 30(10): 15811590.

Ngugi, M.R., D. Doley, M.A Hunt, P. Ryan and P. Dart (2004) Physiological responses to water stress in Eucalyptus cloeziana and E. argophloia seedlings. Trees structure and function Vol. 18, No. 4 pp 381 389.

Netondo, G.W, Onyango J.C and Beck, E. (2004) sorghum and salinity: II Gas Exchange and chlorophyll fluorescence of sorghum under salt stress |Crop Sci. $44 ; 806-811$. 
Ramadhani, T. (2002) Marketing of Indigenous fruits in Zimbabwe socio-economic studies Dev. Vol. 129 wissen chafttsverlag vauk, kiel, Germany.

Saka, J.K.K, Mwendo-phiri, E. and Akinnifesi, F.K. (2002) Community Processing and nutritive value and some miombo indigenous fruits in central and southern Malawi, pp 164 - 169 in Kwesiga, F, Ayuk, E. and Agumya, A. (Eds) Proc. $14^{\text {th }}$ Southern African Regional Review and planning workshop 3-7 September, 2001, Harare Zimbabwe.

Saka, J.K.K, Swai, R, Mkaida, A, Schoraburg A, Kwesia, F and Akinnifesi, F.K. (2004a): Processing and utilization of the indigenous miombo in Southern Africa. Agroforestry impacts livelihoods in Southern Africa: Putting Research into Practice pp 343 - 352 in Rao, M.R, Kwesiga, F.R. (eds) Proc. Regional Agroforestry conference Nairobi, Kenya.

Saka, J.K.K, Swai, R., Mkonda, A, Schoraburg A., Kwesiga, F. and Akinnifesi, F.K (2004b): Processing and utilization of indigenous fruits of the miombo in Southern Africa; putting research into practice, pp 343 - 352 in Rao, M.R, Kwesiga, F.R. (eds) Proc. Regional Agroforestry Conference on Agroforestry Impact on livelihoods in Southern Africa, Nairobi, Kenya.

Sibole, V, Cabot, C, Poschenrieder, and Barcelo, J. (2003) Efficient leaf low partitioning on over riding condition for abscissic acid controlled stomatal and leaf growth responses to $\mathrm{NaCl}$ salinization in two legumes. J. Expt.Bot.54: 2111 - 2119.
Zhang, X, N, Wu and C. Li (2005) physiological and growth responses of Populus davidiana ecotypes to different soil water contents. J. Arid Environments vol. 60, No. 4 pp $567-579$

Schoraburg, A, Mhongo, J. and Akinnifesi, F.K. (2001). Marketing of $U$. Kirkiana and $Z$. Mauritanian fruits and their potential for processing by rural communities in Southern Malawi, pp 169 - 176 in Kwesiga, F, Ayuk, E and Agumya Proc. $14^{\text {th }}$ Southern Regional Review and Planning Workshop $3-7$ September 2001, Harare, Zimbabwe.

Anonymous, (2002) Government of Kenya. Ministry of Agriculture Extension division - Annual Report Nyanza Province.

Anonymous, (2004) Government of Kenya Ministry of Planning and National Development. District development plans for Siaya and Vihiga districts pp 6.

Anonymous, (2006) Government of Kenya, Ministry of Planning and National Development. District development plans for Kisumu.

Atanganan, A.R., Tchoundjen, Z, Foundoun, J. M, Asach, E, Ndoumbe, M. and Leakey, R.R.B (2001) Domestication of irvingia, phenotypic variation in two population from Cameroon. Agroforestry systems 53: $55-611$.

Gachanga, S.P and P. Ilg (1990) Fruit tree nurseries Bulletin, Ministry of Agriculture Nairobi, Kenya, pp 8 16. 